\title{
POULTRY FEED RESOURCES AND CHEMICAL COMPOSITION OF CROP CONTENT OF SCAVENGING INDIGENOUS CHICKEN
}

\author{
Shuna ADMASU1 ${ }^{1}$, Demeke SOLOMON² and Molla MESERET ${ }^{2} \bowtie$ \\ 1 Office of Agriculture, Wollega, Ethiopia \\ 2 Jimma University College of Agriculture and Veterinary Medicine, Ethiopia \\ ${ }^{3}$ University of Gondar, College of Veterinary Medicine and Animal Sciences P.O.Box 196, Ethiopia \\ Email: meseretmo@yahoo.com \\ supporting Information
}

\begin{abstract}
The study was conducted in Genji district of West Wollega Zone with the objectives of characterization of scavenging poultry feed resource base (SFRB) and evaluation of composition of crop content of scavenging indigenous chicken. A total of 60 sampled grower chickens ( $50 \%$ female and $50 \%$ male) at an age of 4-6 month, were purchased fromrural farmers and slaughtered during early dry season to study the physical characteristics and chemical composition of the crop content. About 50.7, 23.85, 12, 8.4 and 5.2\% of the crop contents of experimental chickens were cereal grains, house-hold leftover/kitchen waste, animal proteins (insects/worms), plant/leaves, and none feed materials respectively. There was variation in composition with altitude and sex of birds slaughtered. The mean weight of the crop content obtained from the cockerels (25 $\mathrm{g} /$ day) was significantly lower $(\mathrm{P}<0.05)$ than that of the pullets $(34 \mathrm{~g} /$ day, but there were no significant difference between altitude in mean weight of crop content of the experimental birds slaughtered. According to the result of laboratory analysis, the dry matter, ether extract, ash, crude protein, crude fiber, nitrogen free extract and calculated metabolizable energy content of the crop content were 89.37, 2.48, 14.82, 10.88, 9.35, $62.61 \%$ and $2552.3 \mathrm{kcal} / \mathrm{kg}$ ), respectively. The percent composition of dry matter, ash, crude fiber, and calcium were significantly $(P<0.05)$ higher in the crop content of pullets than in the crop content of cockerels, while crude fiber and crude protein level of the crop contents of the chickens of the mid altitude were significantly higher $(P<0.05)$ than that of the crop content of chickens of the low altitude. The study showed that the nutrient contents of Scavengable feed resources were below the bird's requirements for optimum productivity. In conclusion, Poultry keepers must provide sufficient supplementation to their birds rather than simply throwing leftovers away to the birds.
\end{abstract}

Keywords: Chemical Composition, Crop Content, Indigenous Chicken, Scavengable Feed Resources.

\section{INTRODUCTION}

The Ethiopian poultry industry is dominated by traditional management system in which the birds are left to scavenge for their nutrients with little or no supplementation and separate poultry housing. The scavenging village poultry is of enormous socio-economic significance in Ethiopia, in terms of contribution to human nutrition and family income (Muchadeyi et al., 2007), indicating that the poultry sub-sector has the potential to provide relatively affordable animal protein.The Ethiopian chicken population is estimated to be 59.5 million of which $90.85 \%$ are indigenous, $4.76 \%$ hybrid and $4.39 \%$ are exotic (CSA, 2017). The Ethiopian indigenous chickens show a large variation in body conformation, plumage colour, comb type and productivity (Hassan, 2007). According to CSA (2017) about 37.93\%, 16.04\%, and $46.03 \%$ of the national poultry population are chicks up to 8 weeks, growers aged between 9 and 20 weeks and adult birds of more than 20 weeks of age respectively. About $36.21 \%$ of the total national standing chicken population is hens of which about $\mathbf{2 . 7 4 \%}$ are non-layers. The four major Regional States in terms of land area and human population (Oromia, Amhara, SNNP, and Tigray) collectively account for about $96.32 \%$ of the total national poultry population. Oromia region own about $34.4 \%$ of the total national chicken population and contributes $36 \%$ of the total annual national egg and poultry meat production. The region's rural areas constitute about $97.1 \%$ of the total regional chicken population while the urban areas constitute $2.9 \%$. West Wollega Zone is accountable for about $6.65 \%$ of the total regional chicken population (CSA, 2017).

However, the economic contribution of the Ethiopian poultry sub-sector is not proportional to the huge chicken population of the country, due to the presence of many productions, reproduction and infrastructural constraints (Aberra, 2000; Hassen, 2007). The major poultry production constraints are that of availability, quality and cost of feed ingredients. There is no planned feeding of chickens under traditional village production in Ethiopia and scavenging is almost the only source of diet. The scavenging feed resource base for local birds is inadequate and variable depending on 
season (Yami and Dessie, 1997). There may be deliberate supplementary grain feeding during food crop ripening and harvesting Period. The quantities of supplementation depend on seasonal variation. Scavenging chickens are vulnerable to predation as they need to leave the family dwelling to scavenge for feed. Scavenging for feed away from the family dwelling also results in birds coming into contact with larger numbers of birds from other flocks, facilitating the spread of infection. Newcastle disease is usually cited as the most widespread, particularly during the rainy season.

The Scavenging Feed Resource Base (SFRB) used under the traditional production system, consists of household wastes and edible materials found in the immediate environment, together with a small amount of grain supplements provided by the household (Mehari, 2016). Bekele (2016) indicated that shortage of feed restricted the potential productivity of scavenging local birds to $40-60$ eggs/hen/year. According to Hayat et al. (2016), the nutrient content of the scavenging feed resource base is below the requirements of the scavenging local chickens and the available scavenging feed resource is inadequate in quantity and deficient in all the nutrients required.

Unfortunately, however, the amount of feed available for scavenging in relation to the carrying capacity of the land areas and flock dynamics across the different seasons and agro-ecologies is still not adequately quantified. Scavenging poultry feed resources, its challenges and coping mechanisms are significant gaps that need to be assessed for the purpose of intervention. Feed is one of the cornerstone challenges of poultry production. The available scavenging feed resource base need to be identified aimed at the rational utilization of locally available feed resources. This being the case, the objective of this research was characterization of scavenging poultry feed resource base and chemical composition of crop content.

\section{MATERIALS AND METHODS}

\section{Ethical approval}

The scientific and ethics committee of the College of Agriculture and Veterinary Medicine, Jimma University approved the study protocol.

\section{Description of the Study Area}

This study was conducted in Genji district (woreda) of Western Wollega Zone of Oromia Regional State, located at $544 \mathrm{~km}$ west of Addis Ababa. Geographically, Genji district is located at southwest of West Wollega Zone between $8^{\circ} 57,30^{\prime \prime}$ and $9^{\circ} 7,30^{\prime \prime}$ North latitude and $35^{\circ} 30,0^{\prime \prime}$ and $35^{\circ} 45,0^{\prime \prime}$ East longitude. The woreda was stratified in to two agro ecological zones (mid altitude and low altitude), ranging between 1420 and 2500 m.a.s.l. The minimum and maximum annual temperature of the woreda varies from 16 to $25^{\circ} \mathrm{C}$, respectively. The study area received annual rainfall ranging between 1225 and 2000 millimeter. The soil type found in the study area is clay (80\%) and sandy soil (20\%).

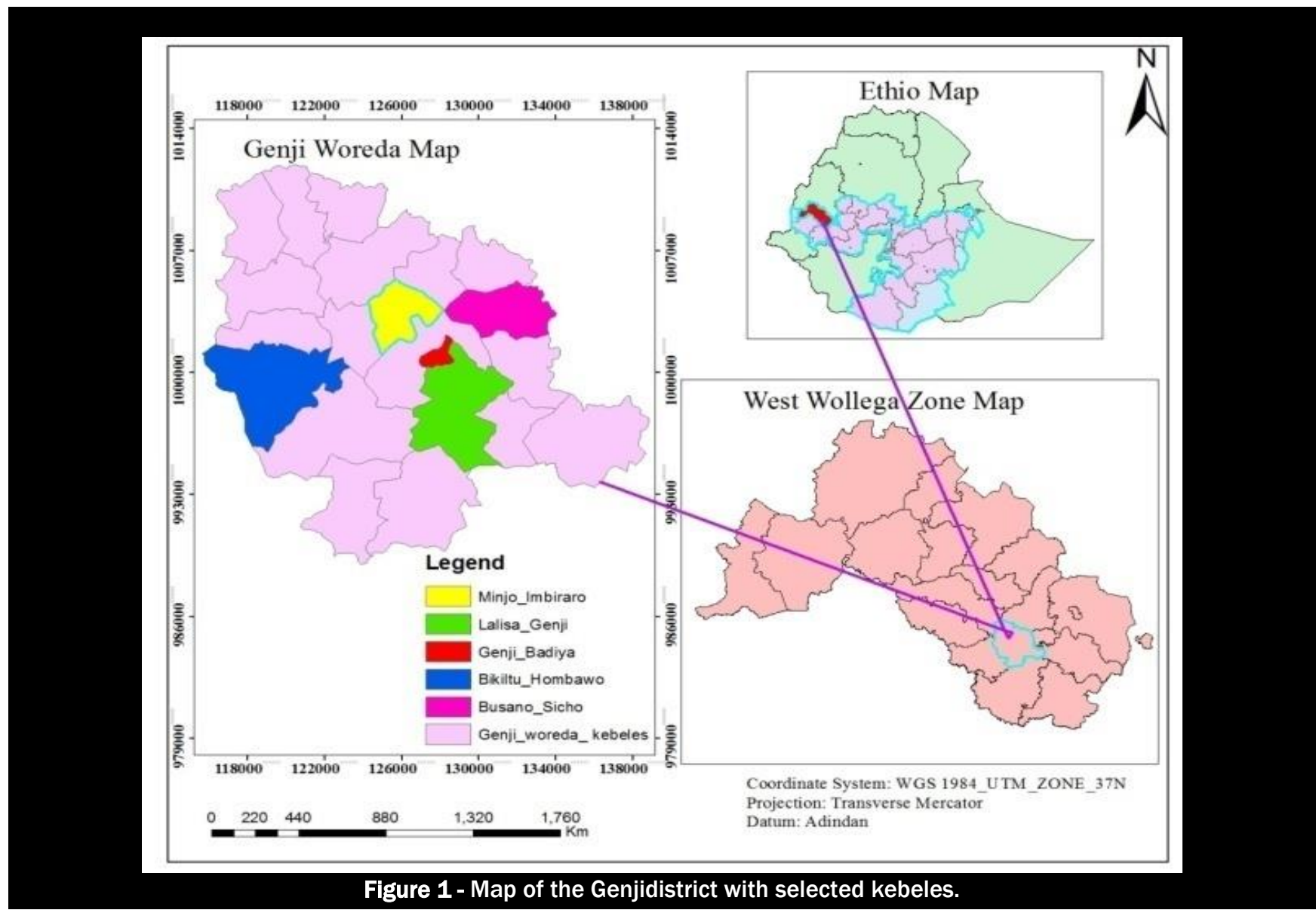




\section{Study of Crop Contents}

Thirty households were selected based on ownership of scavenging chicken and willingness to further participate on crop content experiment. A contractual agreement was arranged with a total of 30 households (6 farmers from each Kebele) for the purpose of purchasing experimental chickens. A total of 60 grower chickens (30 pullets and 30 cockerels) between an age of 4-6 months (six from each Kebele) were purchased on the basis of physical appearance and information provided by the participating households. The chickens purchased were picked up from the households flock between 5.00 and $6.00 \mathrm{pm}$ (local time) considered being the last hours of scavenging. The chickens were directly transported to the Genji town slaughter house in cages and slaughtered between 6:00 and 7:00 pm. The birds were individually weighed, slaughtered and allowed to bleed for five minutes. This was followed by socking in boiled water, feather plucking and evisceration. Crops were carefully removed from each of the slaughtered bird and weighed using sensitive electronic balance. Crop material was visually examined and separated in to different categories. Finally the crop content was air dried for one day and transported to Addis Ababa'JJJE' Analytical Testing Service laboratory for chemical analysis.

\section{Laboratory Chemical Analysis}

The crop content was oven dried at $65^{\circ} \mathrm{c}$ to a constant weight and was grinded to pass through $1 \mathrm{~mm}$ screen. The grinded materials were stored in tight plastic bags until required for laboratory chemical analysis. The materials were analyzed for proximate components i.e. the Dry Matter (DM) content was determined according to the standards of the Association of Official Analytical Chemists (AOAC, 2000) official methods the crop content per sample was heated in an Oven dry at $130^{\circ} \mathrm{C}$ for 3 hours. Crude protein was determined using nitrogen to protein conversion factor of 6.25 to convert total nitrogen to CP. The crude fiber (CF) was determined according to AOAC (2000) using Ceramic Fiber Filter method. Ether Extracts was determined according to AOAC (2000) Official method using Sohxlet apparatus.

Ash content was determined according to AOAC (2000) Official direct method using incinerating the sample at 550 ${ }^{\circ} \mathrm{C}$ for 16 hours. Calcium was determined according to AOAC (2000) with the use of EDTA Titration. Phosphorus was determined according to AOAC (2000) with the use of Vanadomolybdo phosphoric acid. Nitrogen Free Extract (NFE) was calculated by difference as: $100-(C P+C F+E E+A s h)$. The Metabolizable Energy content of the materials was estimated using the formula adopted by Wiseman, (1987), with the assumption that TME is $8 \%$ higher than ME (Rashid et al., 2005).

$\mathrm{TME}\left(\mathrm{Kcal} / \mathrm{kg}^{-1} \mathrm{DM}\right)=(3951+54.4 \mathrm{EE}-88.7 \mathrm{CF}-40.8 \mathrm{Ash})$.

Where: $\mathrm{EE}=\%$ composition of ether extract on $\mathrm{DM}$ basis. $\mathrm{CF}=\%$ composition of crude fiber on DM basis. Ash=\% composition of total ash on DM basis. The conversion factor of 238.85 kilo calorie (Kcal) equivalents to 1 Mega joule (MJ) was used to convert Kcal to MJ.

\section{Statistical Data Analysis}

Data collected from crop content of experimental chicken and laboratory chemical analysis were normally distributed and analyzed using the General Linear Models (GLM) procedure using SAS, 2009 (Version 9.3) (Littell et al., 2002). The $5 \%$ significant level should be considered based on the following model.

$Y=\mu+s i+a j+(s a) i j+E i j$

$\mathrm{Yij}=$ an observation for a given variable

$\mu=$ overall mean.

si $=$ effect of the ith sex of the bird ( $i=1$ cockerel, 2 pullets)

$a j=e f f e c t$ of the jth altitude of the study area $(j=1$ low altitude, 2 Mid altitude)

(as) $\mathrm{ij}=$ effect of interaction between sex and altitude of the study area..

Eij $=$ residual random error.

\section{RESULTS AND DISCUSSION}

\section{Weights of live bird and crop content}

The results of the quantity and crop content of the experimental birds are given in Table 2 . The results showed that the mean live weight of the cockerels and pullets slaughtered for the determination of crop content was 1.4 and $1.23 \mathrm{~kg} /$ bird respectively. The result showed that the mean live weight of the experimental sampled pullet were significantly lower $(P<0.05)$ than the mean live weight of the cockerels. The result of the current study was in line with that of Hayat et al. (2016) who reported that the mean live weight of indigenous pullets and cockerels in SekaChokorsa was 1.12 and 1.4 $\mathrm{kg} / \mathrm{head}$, respectively. There was significant difference $(P<0.05)$ between cockerels and pullets in mean body weight at slaughtering while there was no significant difference $(P>0.05)$ between either the experimental cockerels or pullets obtained from low land and midland agro ecology in mean body weight at slaughter. The results obtained showed that, the mean total crop content obtained from pullets and cockerels was 34 and $25 \mathrm{~g}$, respectively. The results of the current study was in agreement with that of Mekonnen et al. (2010) who reported that hens have better scavenging capacity probably to meet the nutrient requirement for egg production. According to McBride et al. (1999), the male would be most of the time on guard and show an alert position while females keep on scavenging. The males call to the hens when they find edible items to share through the performance of "tidbitting" displays by picking up and dropping the food repeatedly and offering it to the hen. During the breeding season, males become very territorial and guard fixed areas and dominant males patrol the boundaries of their territory. 


\section{Physical characteristics of the crop content}

The scavenging feed resources of the study area as measured by the physical visual appraisal of the crop content of slaughtered chicken comprised of household scraps, animal protein sources (worms, small snails, grass hoppers, ants termites), grains (maize, sorghum, millet, teff, barley), green materials (leafs and grass) and other inedible materials. The results of the visual appraisal indicated that (in order of importance), the major components of the crop contents were cereal grains, household scraps, insects and worms, plants and inedible materials. Significant interactions between altitude and sex of birds were observed with regard to the crop weight, grain, insects/worms, plant material and other content.

The fresh crop contents obtained from the slaughter chickens considerably varied based on altitude and sex of the slaughtered chickens (Table 1). However, there was significant difference $(P<0.05)$ between altitudes in the cereal grain proportion of the crop content of the experimental chickens. Cereal grains represent the largest proportion of the scavengeable feed resources of both lowland and mid altitude agro-ecologies studied. The scavenging feed resource of both the lowland and mid altitude ecologies of the study area, as measured by crop content of the slaughtered chickens comprised of cereal grains, refused household, green materials, insects/worms and other materials, all of which showed some sort of variation between individual birds.

As shown in Table 1, there was no significant difference between the pullets and cockerels in mean daily insect and worm and green materials $(P>0.05)$ proportion of the crop contents. Cereal grains comprised of about 53.3 and $48.1 \%$ of the total crop content of the slaughtered pullets and cockerels respectively. Maize, sorghum and millets were the cereal grains frequently encountered during the crop content analysis both in lowland and midland. The relatively higher proportion of cereal grains recorded from the crop content of the slaughtered chickens could be attributed to the harvest time of grains which takes place at early dry period (October- December) in the study area. The proportion of cereal grains obtained from crop content of pullets $(53.3 \%)$ was significantly higher $(\mathrm{P}<0.05)$ than the proportion of cereal grains obtained from the crop content of cockerels (48.1\%). Thus the results obtained indicated that the mean daily cereal grain and total feed material intake of the pullets was significantly $(P<0.05)$ higher than that of the cockerels. The relatively higher mean daily grain and total feed material intake of the pullets seems to be due to the fact that females require more nutrients than males to meet their production and reproduction performance.

Table 1 - Effect of altitude and sex of birds on the crop content of experimental chickens (Mean \pm SE)

\begin{tabular}{|c|c|c|c|c|c|c|c|}
\hline \multirow{2}{*}{$\begin{array}{l}\text { Altitude } \times \text { Sex } \\
\text { of birds }\end{array}$} & \multicolumn{7}{|c|}{ Composition (\% fresh bases) } \\
\hline & $\begin{array}{l}\text { Body wt } \\
\text { (kg) }\end{array}$ & $\begin{array}{l}\text { Crop wt } \\
\text { (gm) }\end{array}$ & $\begin{array}{l}\text { Cereal grains } \\
(\%)\end{array}$ & $\begin{array}{l}\text { Household } \\
\text { Refused (\%) }\end{array}$ & $\begin{array}{c}\text { Insect/worm } \\
\text { (\%) }\end{array}$ & $\begin{array}{l}\text { Plants } \\
(\%)\end{array}$ & $\begin{array}{l}\text { Others } \\
(\%)\end{array}$ \\
\hline \multicolumn{8}{|l|}{ Altitude } \\
\hline Lowland (30) & $1.34 \pm 0.02$ & $28 \pm 0.3$ & $48.1 \pm 1.18^{b}$ & $23.43 \pm 0.89$ & $9.88 \pm 0.38^{b}$ & $7.37 \pm 0.28^{b}$ & $5.86 \pm 0.38 \mathrm{a}$ \\
\hline Midland (30) & $1.35 \pm 0.02$ & $31 \pm 0.3$ & $52.97 \pm 1.18^{a}$ & $24.33 \pm 0.89$ & $11.22 \pm 0.38^{a}$ & $8.83 \pm 0.28^{a}$ & $4.28 \pm 0.38^{b}$ \\
\hline P-Value & 0.654 & 0.701 & 0.005 & 0.476 & 0.017 & 0.001 & 0.006 \\
\hline \multicolumn{8}{|l|}{ Sex of birds } \\
\hline Cockerels (30) & $1.41 \pm 0.02^{a}$ & $25 \pm 0.3^{b}$ & $48.1 \pm 1.18^{b}$ & $23.1 \pm 0.89$ & $10.98 \pm 0.38$ & $7.93 \pm 0.28$ & $4.94 \pm 0.38$ \\
\hline Pullets (30) & $1.23 \pm 0.02^{b}$ & $34 \pm 0.3^{a}$ & $53.3 \pm 1.18^{a}$ & $24.7 \pm 0.89$ & $10.11 \pm 38$ & $8.26 \pm 0.28$ & $5.2 \pm 0.38$ \\
\hline P-Value & 0.001 & 0.001 & 0.001 & 0.203 & 0.1097 & 0.411 & 0.642 \\
\hline \multicolumn{8}{|c|}{ Altitude $\times$ sex of birds } \\
\hline $\mathrm{L} \times \mathrm{C}$ & $1.42 \pm 0.02^{a}$ & $22 \pm 0.4^{b}$ & $48.52 \pm 1.67 \mathrm{ab}$ & $22.67 \pm 1.26$ & $10.24 \pm 0.54 \mathrm{ab}$ & $6.87 \pm 0.4^{b}$ & $5.89 \pm 0.55^{a}$ \\
\hline$L \times P$ & $1.39 \pm 0.02^{a}$ & $33 \pm 0.4^{b}$ & $47.67 \pm 1.67^{b}$ & $23.47 \pm 1.26$ & $9.51 \pm 0.54^{b}$ & $7.87 \pm 0.4^{\mathrm{ab}}$ & $4.00 \pm 0.55^{b}$ \\
\hline$M \times C$ & $1.28 \pm 0.02^{b}$ & $27 \pm 0.4^{a}$ & $53.37 \pm 1.67^{a}$ & $24.19 \pm 1.26$ & $11.73 \pm 0.54^{a}$ & $9.00 \pm 0.4^{a}$ & $5.83 \pm 0.55^{a}$ \\
\hline$M \times P$ & $1.28 \pm 0.02^{b}$ & $34 \pm 0.4^{a}$ & $52.57 \pm 1.67 \mathrm{ab}$ & $25.2 \pm 1.26$ & $10.7 \pm 0.54^{\mathrm{ab}}$ & $8.67 \pm 0.4^{a}$ & $4.57 \pm 0.55^{\mathrm{ab}}$ \\
\hline P-Value & 0.001 & 0.001 & 0.001 & 0.530 & 0.001 & 0.001 & 0.001 \\
\hline
\end{tabular}

The results of this study was in agreement with that of Hayat et al. (2016) who reported that cereal grains comprised the highest proportion of the crop content of the experimental chickens, in SekaChokorsa district of South Western Ethiopia. Furthermore this result was similar with that of Tadelle and Ogle (2000) who reported that seeds comprised the largest proportion of the feed materials present in the crop, followed by plant material, worms, insects and un-identified materials, respectively from study conducted in central high lands of Ethiopia. As shown in Table 1, there was no significant difference between lowland and mid altitude in mean total crop content and in the proportion of household refusal obtained from the slaughtered chickens $(P>0.05)$. The household refusal obtained from both altitudes mainly consisted of kitchen leftovers (porridge and its waste products, refused injera, bread, potatoes and onion pills), maize, and other grain by-products generated during the traditional household food preparation.

The results obtained showed that the mean daily grain intake recorded in the low land (48.1\%) was significantly lower $(\mathrm{P}<0.05)$ than that recorded in the mid altitude $(52.97 \%)$. Similarly, the proportion of insect and worms and green 
plant materials obtained from crop content of slaughtered chicken of midland was significantly higher $(P<0.05)$ than that of the crop content of slaughtered chickens of the low altitude, attributed to the difference in the availability of protein source feed and green forages in the area In contrary to the result of this study, Tadelle (1996) reported that there is no difference in the availability of insects/worms with the midland and low land altitude, from crop contents of experimental chicken studied in central highland of Ethiopia. The proportion of animal protein source in the crop content of the slaughtered chickens was lower for the lowland. The inedible organic materials found in the crop of the slaughtered chickens comprised of soil, sand (grits), charcoals and others. The proportion of these materials was significantly higher $(P<0.05)$ in the crop content of lowland chickens. But, there was no significant difference $(P>0.05)$ in the proportion of inedible organic materials between pullets and cockerels.

\section{Chemical composition of crop contents}

The chemical composition of crop contents of the experimental chickens is shown in Table 2. There was no significant difference $(P>0.05)$ between the crop content of slaughtered chickens of the lowland and mid altitude in percent composition of dry matter, total ash, crude fiber, metabolizable energy, calcium and phosphorus. The percentage composition of ether extract and nitrogen free extract of the crop content of the slaughtered chickens of the lowland was significantly higher $(P<0.05)$ than that of the crop content of the slaughtered chickens of the mid altitude. On the contrary, the percentage composition of crude protein of the crop content of slaughtered chickens of the mid altitude was significantly higher $(\mathrm{P}<0.05)$ than that of the crop content of slaughtered chickens of the lowland altitude. Significant interactions between altitude and sex of bird were observed with regard to the DM, EE, CP, CF and NFE level of composition (Table 2). The relatively higher percentage of the crude protein content of the crop content of slaughtered chicken of the mid altitude could be attributed to the better availability of protein rich scavenging feed resources.

The dry matter contents of experimental pullets and cockerels were $89.86 \%$ and $89.38 \%$, respectively and shows no significant difference between each other's $(P>0.05)$. With the exception of the percentage composition of dry matter, there was no significant difference in the percentage composition of all the other nutrients between the crop content of the slaughtered pullets and cockerels. The mean percentage composition of dry matter and total ash of the crop contents of slaughtered pullets was higher than that of slaughtered cockerels. The relatively higher percentage of dry matter and total ash recorded from the crop content of pullets could be attributed to the high proportion of grains in their crop contents. It was also reported that the higher proportion of grains in the crop content of pullets might be a reflection of the preferential treatment given to the adult birds in grain supplementation by the local people. They believe that since the layers lay eggs or rear the chicks, they should have more feed. This result is lower than that of Mekonnen et al. (2010) who reported that the higher dry matter (91.1-92.5\%) composition of the crop content might be due to conducting the study in harvesting season. On the other side the result of the current study was contrary to that of Ncobela (2015) who reported that the dry matter concentration of crop content was higher in the hot dry season in cocks than in hens from the experimental chicken conducted in South Africa. The crude protein level of crop content of the experimental birds significantly $(P<0.05)$ varied with altitude but there was no significant difference $(P>0.05)$ in crude protein between the crop content of males and females (Table 2). The mean crude protein level of the crop contents of experimental birds of the mid altitude and low altitude was $\mathbf{1 2 . 1 7}$ and $9.47 \%$ of the dry matter respectively.

The mean CP contents of the crop content of the study area was $10.88 \%$, indicating that the result of the current study was lower than that of Momoh et al. (2010), who reported crude protein of $12.77 \%$ from crop content during early dry season, but was in agreement with that of $10.94 \%$ the value of which was recorded from the crop content studied during late dry season in Nigeria. The percent composition of CP obtained from the current study was higher than that of Hayat et al. (2016) who reported CP of 9.76\% from crop contents of indigenous scavenging chicken of SekaChokorsa. The results of this study showed that growing chicken tended to consume feed with a higher crude protein content. According to the results of this study, the crude protein content of the crop content of the experimental birds was below the requirement (160 g Kg DM-1) of local laying hens. Kinghori et al. (2003) reported that the CP requirement of indigenous chickens at $14-21$ weeks of age is $160 \mathrm{~g} \mathrm{~kg}^{-1}$. Based on the results of the current study, the total CP content of the crop content of laying hen was calculated to be $108.2 \mathrm{~g} \mathrm{~kg}^{-1}$ the value of which was lower than the requirement of laying hen. According to NRC (1994), the recommended levels of CP in diets of egg type growers range between 150 and $200 \mathrm{~g} / \mathrm{kg}$ of DM. The crude protein level of the crop content obtained from the current study was lower in low altitude than in mid altitude. The low CP content of the crop contents of experimental birds from the low altitude could be attributed to the poor vegetation cover and soil fertility and relatively low proportion of seeds in the crops of the slaughtered birds.

There was no significant difference $(P>0.05)$ between altitudes and sex of birds in the percent composition of crude fiber of the crop contents of experimental birds. Whereas, there the significant difference $(P<0.05)$ on the interaction effect of altitude with sex of birds. On the contrary, the percentage composition of CF obtained from the crop content of pullets (9.56\%) was higher than that of the cockerels (9.14\%). The overall mean percent composition of CF of the crop content obtained in this study was $9.35 \%$. This result was in line with that of Momoh et al. (2010), who reported CF content of 9.95 and $\mathbf{8 . 9 1 \%}$ from crop contents of the Nigerian indigenous chickens during early and late dry season respectively. 


\begin{tabular}{|c|c|c|c|c|c|c|c|c|c|}
\hline \multirow{2}{*}{$\begin{array}{l}\text { Altitude/Sex of } \\
\text { bird }\end{array}$} & \multicolumn{9}{|c|}{ Chemical Composition (\% of dry weight) } \\
\hline & DM & Ash & EE & $\mathbf{C P}$ & $\mathbf{C F}$ & NFE & ME (Kcal) & $\mathbf{C a}$ & $\mathbf{P}$ \\
\hline \multicolumn{10}{|l|}{ Altitude } \\
\hline Lowland & $89.15 \pm 0.14$ & $14.5 \pm 0.3$ & $2.92 \pm 0.16^{a}$ & $9.47 \pm 0.37^{b}$ & $9.38 \pm 0.24$ & $63.69 \pm 0.65^{a}$ & $2584.7 \pm 23.2$ & $1.15 \pm 0.06$ & $0.83 \pm 0.12$ \\
\hline Midland & $89.1 \pm 0.14$ & $15.1 \pm 0.3$ & $2.05 \pm 0.16^{b}$ & $12.17 \pm 0.37^{a}$ & $9.32 \pm 0.24$ & $61.54 \pm 0.65^{b}$ & $2519.9 \pm 23.2$ & $1.01 \pm 0.06$ & $0.65 \pm 0.12$ \\
\hline P-Value & 0.803 & 0.222 & 0.006 & 0.001 & 0.852 & 0.048 & 0.084 & 0.136 & 0.334 \\
\hline \multicolumn{10}{|l|}{ Sex of birds } \\
\hline Cockerel & $88.86 \pm 0.14^{b}$ & $15.02 \pm 0.3$ & $2.61 \pm 0.16$ & $11.05 \pm 0.37$ & $9.14 \pm 0.24$ & $62.35 \pm 0.65$ & $2569.1 \pm 23.2$ & $0.92 \pm 0.06^{b}$ & $0.68 \pm 0.12$ \\
\hline Pullet & $89.38 \pm 0.14^{a}$ & $14.62 \pm 0.3$ & $2.36 \pm 0.16$ & $10.59 \pm 0.37$ & $9.56 \pm 0.24$ & $62.87 \pm 0.65$ & $2535.6 \pm 23.2$ & $1.24 \pm 0.06^{a}$ & $0.79 \pm 0.12$ \\
\hline P-Value & 0.031 & 0.372 & 0.321 & 0.404 & 0.261 & 0.584 & 0.337 & 0.005 & 0.532 \\
\hline \multicolumn{10}{|c|}{ Altitude*sex of birds } \\
\hline$L \times C$ & $89.15 \pm 0.2^{\mathrm{ab}}$ & $14.71 \pm 0.42$ & $3.22 \pm 0.23 a$ & $9.5 \pm 0.53^{b}$ & $9.6 \pm 0.34^{a b}$ & $62.9 \pm 0.92^{a b}$ & $2574.8 \pm 32.8$ & $0.94 \pm 0.15$ & $1.08 \pm 0.17$ \\
\hline$L \times P$ & $89.15 \pm 0.2^{\mathrm{ab}}$ & $14.38 \pm 0.42$ & $2.62 \pm 0.23^{a b}$ & $9.44 \pm 0.53^{b}$ & $9.17 \pm 0.34^{\mathrm{ab}}$ & $64.4 \pm 0.92^{a}$ & $2594.6 \pm 32.8$ & $1.26 \pm 0.15$ & $1.24 \pm 0.17$ \\
\hline$M \times C$ & $88.57 \pm 0.2^{b}$ & $15.34 \pm 0.42$ & $1.99 \pm 0.23^{b}$ & $12.6 \pm 0.53^{a}$ & $8.68 \pm 0.34^{b}$ & $61.72 \pm 0.92^{\mathrm{ab}}$ & $2578.9 \pm 32.8$ & $0.85 \pm 0.15$ & $1.29 \pm 0.17$ \\
\hline$M \times P$ & $89.62 \pm 0.2^{a}$ & $14.87 \pm 0.42$ & $2.11 \pm 0.23^{b}$ & $11.73 \pm 0.53^{a}$ & $9.95 \pm 0.34 a$ & $61.35 \pm 0.92^{b}$ & $2476.5 \pm 32.8$ & $1.3 \pm 0.15$ & $1.36 \pm 0.17$ \\
\hline P-Value & 0.031 & 0.873 & 0.016 & 0.001 & 0.001 & 0.036 & 0.143 & 0.79 & 0.759 \\
\hline
\end{tabular}


The CF content of crop obtained in the current study was lower than that of Hayat et al. (2016), who reported CF of 11.92 and $11.07 \%$ from crop contents of pullets and cockerels from the study conducted in SekaChokorsa. On the other side, the CF values recorded from the current study was higher than that of Mekonnen et al. (2010) and Raphulu et al. (2015), who reported CF content of 3.65 and 3.3\% from crop content of egg type adult and grower chicken of Ada'a district of Oromia Region and South Africa, respectively. The CF content obtained in this studywas higher than the CF level recommended with in commercial layers rations of around 5\% (Feltwell and Fox, 1978). Excessive Crude Fiber composed of cellulose, lignin and hemi-cellulose is likely to be poorly digested by mono-gastric animals (Mekonnen et al., 2010). The consumption of undesirable materials such as feathers may contribute to high levels of CF in crop contents and results in poor availability of nutrients (Sonaiya et al., 1999).

Carbohydrate is the major source of energy for poultry and most of the carbohydrate in poultry diets is provided by cereal grains. The NFE represents soluble carbohydrates and other digestible and easily utilizable non-nitrogenous substances in chicken feeding. According to the results of the current study, there was significant difference in NFE levels of crop content $(P<0.05)$ between altitude and interaction effect of sex with altitude.

Mean percent composition of $\mathbf{6 2 . 6 1 \%}$ of NFE value was obtained from the crop content of the experimental birds of the current study. The result of the current study was higher than that of Hayat et al. (2016), who reported NFE value of 46.2\% from crop contents of the experimental chickens in SekaChokorsa Woreda. The result of the current study was also higher than that of Momoh et al. (2010), who indicated 53.62 and $\mathbf{5 6 . 2 6 \%}$ of NFE from crop content of the experimental birds during early and late dry seasons of North Central Nigeria respectively. Ncobela (2015) reported 33.9 and $30.02 \%$ of NFE from crop contents of experimental chicken in South Africa. Rashid et al. (2005) and Raphulu et al. (2015) reported about 68.7 and $61.03 \%$ of NFE from crop contents of the experimental chicken in Bangladesh and Venda region of South Africa, respectively. The higher NFE value indicates higher proportion of grains in the crops during late and early dry seasons. Higher NFE content is associated with higher metabolizable energy.

The mean calculated metabolizable energy level of the crop contents of the experimental chicken of the current study was $2552.3 \mathrm{Kcal} / \mathrm{kg}$. Tadelle and Ogle (2000) reported comparable metabolizable energy content of 2245.1$3528.1 \mathrm{Kcal} / \mathrm{kg} \mathrm{DM}-1$ from crop contents of the experimental chickens of central highland of Ethiopia. Higher energy content was reported during early dry season compared to the other seasons, attributed to the better availability of cereal grains which had just been harvested and given to the birds in larger amounts. The result of the current study was higher than that of Hayat et al. (2016) who reported 2023 and $2082 \mathrm{Kcal} / \mathrm{kg}-1$ for pullets and cockerels respectively.

Momoh et al. (2010) reported metabolizable energy value of 2352 and $2598 \mathrm{Kcal} / \mathrm{kg}-1$ from crop content of layers and grower during the early dry period in Nigeria. There is no an efficient utilization of the metabolizable energy by scavenging chickens since some energy could be lost due to their movement over a long distance to find feed. According to NRC (1994) the relative amounts of energy available vary with the amount and composition of the feedstuffs in the scavenging feed resource. Other factors, such as species, genetic makeup and age of poultry, as well as the environmental conditions also influence the utilization of dietary energy. Deficiency of energy negatively affects the production performance of poultry. If the available energy concentration of the diet is changed, birds maintain constant energy intakes by changing their feed intakes. Therefore, energy is required for chickens for supporting movement activities during scavenging.

The Ash level of the crop content of the experimental chickens was not significantly influenced $(P>0.05)$ by altitude and sex of the birds. The mean ash content of the crop content observed in this study was $14.82 \%$. This result was in agreement with that of Tadelle and Ogle (2000) who reported ash content of $1.6-15.7 \%$ from the crop content of indigenous chickens during dry season in Central Highland of Ethiopia. The result of current study was lower than that of Hayat et al. (2016), who reported ash content of 22.86 and $22.15 \%$ for crop content of pullets and cockerels in SekaChokorsa.

Calcium levels of the crop contents of the experimental chicken was significantly $(P<0.05)$ higher $(1.24 \%)$ in pullets than in $(0.92 \%)$ in the cockerels. The overall mean calcium content of experimental chicken was $1.1 \%$. The result of the current study was lower than $1.32 \%$ reported by Rashid et al. (2004) from Pakistan. The higher calcium content in the crop content of pullets compared to that of cockerels might be attributed to a selective feeding habit of the pullets which in turn depends upon the nutritional requirement during the early phase of laying period. Calcium requirement (18 $\mathrm{g} \mathrm{kg}$ DM-1 of laying hens is comparatively high and increases with the rate of egg production and age of the hen.

The phosphorus content of the crop content obtained in the current study was $0.68 \%$ and $0.79 \%$ for cockerels and pullets, respectively. The mean phosphorus content of the crop content of the experimental chicken in the study area was $0.74 \%$. This result is higher than that of Tadelle and Ogle (2000), who reported 0.9 and $0.6 \%$ of Calcium and Phosphorus from crop content of indigenous chickens in the Central Highland of Ethiopia. The result of this study was in line with that of Hayat et al. (2016) who reported calcium content of 1.26 and $0.73 \%$ for pullets and cockerels, and phosphorus content of 0.66 and $\mathbf{0 . 6 8} \%$ from a study conducted in SekaChokorsa Woreda. The result of the current study was higher than that of Mekonnen et al. (2010) who reported 0.43-0.9\% Calcium and 0.24-0.38 \% phosphorus from the crop content in Ada'a district. Rashid et al. (2005) reported 0.46 and $0.34 \%$ of Phosphorus from crop content of scavenging layers and growers in Bangladesh. Poultry need Phosphorus and Calcium to build and maintain their skeletons. Phosphorus is also necessary for energy utilization at the cellular level (NRC, 1994). However, phosphorus is unavailable to the birds because it is found in the phytate form which is being excreted in to the environment (Tahir et al., 2012). The low Calcium content obtained 
from the current study indicate low availability of green forage during dry season in the study area. It is indicated that lower proportion of green forages was found in crop content of most village chickens during the harvesting season.

\section{CONCLUSION}

The present study indicated that the quantity of scavengeable feed resources in the Genji district and their chemical composition were varied with agro ecologies. The result further indicated that feed resources scavenged by local chickens were showed variation among sex of birds. During the study period the availability of cereal grains and house hold refusal /kitchen wastes were higher when compared with green plants and insects/worms observed in the crop contents of local chickens. It can also be concluded that the major nutrients such as calcium, crude protein and Metabolizable energy in crop contents appeared to be low in nutritional status of scavenging local chickens under small holder management condition except for Phosphorus. Generally the results of the current study indicated that the nutrient content of scavengeable feed resources base of Genji district is below the requirements of scavenging local chickens. This might be attributed to the lack of knowledge about the importance of supplementary feeding and very little attention given for poultry management. A wide range cereal grains available in the district to be used as supplementary source of energy. However, scavengeable feed resources alone cannot support optimal growth and egg production of local chickens. Therefore, adequate feed supplementation based on composition of the available SFR is necessary for improved productivity of the local scavenging chickens.

\section{DECLARATIONS}

\section{Consent to publish}

Not applicable.

\section{Competing interests}

The authors declare that they have no competing interests.

\section{Funding}

This study was funded by the Jimma University. The views presented in the article are of the authors and do not necessarily express the views of the funding organization. Jimma University was not involved in the design of the study, data collection, analysis, and interpretation.

\section{Authors' contributions}

Admasu Shuna (AS) conceived the study, coordinated the overall activity, and carried out the statistical analysis, drafted the manuscript. Solomon Demeke (SD) participated in drafting and reviewing the manuscript and conceived the study, coordinated the overall activity, and reviewed the manuscript. Meseret Molla (MM) participated in drafting and reviewing the manuscript. Participated in the design of the study, and reviewed the manuscript. All authors read and approved the final manuscript.

\section{Availability of data and materials}

Data will be made available up on request of the primary author

\section{Acknowledgment}

First of all, the authors would like to express their sincere gratitude to the study participants for their willingness to take part in the study. The authors have heartfelt thanks to Jimma University for the financially supporting.

\section{REFERENCES}

Aberra M (2000). Comparative studies on performance and physiological responses of Ethiopian indigenous (Angete-melata) chicken and their F1 crosses to long term heat stress. PhD thesis. Martin Luther University, Halle Witten berg, Berlin, Germany. 182.

Alemu Y and Tadelle D (1997). The status of poultry research and development in Ethiopia. Research bulletin No. 4, DebreZeit, Ethiopia.

AOAC (2000). Official Methods of Analysis. 17 th ed. The Association of Official Analytical Chemists.Alington, V.A., USA.

Bekele B (2016). Locally Available Poultry Feeds, Feeding Practices and Health in Sidama Zone and Halaba Special Woreda in SNNPR. Journal of Biology, Agriculture and Healthcare, 6(7): 2224-3208.

CSA (2017). Agricultural Sample Survey 2016/17 (2009 E.C). Volume II. Report on Livestock and livestock characteristics. Statistical Bulletin, 505. November, Addis Ababa, Ethiopia

Gunaratne SP, Chandrasiri ADN, Hemalatha, WAP, and Roberts JA (1993). Feed resource base for scavenging village chickens in Sri Lanka. Tropical Animal Health and Production, 25:249-257.

Hassen H (2007). Phenotypic and genetic characterization of indigenous chicken populations in northwest Ethiopia. PhD Thesis, University of the Free State, Bloemfontein, South Africa.

Hayat N, Solomon D and Meseret M (2016). Chemical composition of scavenging feed resource of indigenous chickens. Asian Journal of Animal Sciences, 10: 182-188.King'ori AM (2003). The protein and energy requirements of indigenous chickens of Kenya,

Littell RC, Stroup WW and Freund RJ (2002). SAS for Linear Models, SAS institute.

Mazengia H, Siraw G and Nega M (2012). Challenges and prospects of village-based exotic chicken development strategy in Amhara regional state, Northwest Ethiopia. Global Journal of Science Frontier Research Agriculture and Veterinary Science, 12(10):2249-4626 
McBride G, Parer IP and Foenander F (1969). The social organization and behaviour of the feral Domestic fowl. Animal Behaviour Monographs, 2:125-181.

Mehari K (2016). Poultry production systems and its feed resources in Ethiopia: A research review. Scientific Journal of Animal Science, 5(2): 220-227.

Mekonnen H, Kelay B and Berhan T (2010). Assessment of the nutritional status of indigenous scavenging chickens in Ada'a district, Ethiopia. Tropical Animal Health and Production, 42: 123-130.

Momoh OM, Egahi JO, Ogwuche PO and Etim VE (2010).Variation in nutrient composition of crop contents of scavenging local chickens in North Central Nigeria. Agriculture Bio. J. North Am., 1: 912-915.

Muchadeyi F, Sibanda S, Kusina N, Kusina J and Makuza S (2007). The village chicken production system in Rushinga District of Zimbabwe. Livestock Research for Rural Development, 16: 40 http://www.Irrd.org/Irrd16/6/much16040.htm

Ncobela CN and Chimonyo M (2015). Potential of using non-conventional animal protein sources for sustainable intensification of scavenging village chickens: A review. Animal Feed Science and Technology, 208: 1-10.

NRC (1994). Nutrient Requirements of Poultry. 9th ed., National Academy Press, Washington, DC, USA, ISBN-13: $9780309048927: 155$. PhD. Thesis, Egerton University, Kenya

Raphulu T, JansenvanRensbur C and van Ryssen JBJ (2015). Assessing nutrient adequacy from the crop contents of free-ranging indigenous chickens. South African Journal of Animal Science, 45(2).

Rashid MM, Islam MN, Roy BC, Jakobsen K and Lauridsen C (2005). Nutrient concentrations of crop and gizzard contents of indigenous scavenging chickens under rural conditions of Bangladesh. Livestock Research for Rural Development, 17, www.Irrd.org/Irrd17/2/rash17016.htm.

Rashid MM, Roy BC and Asaduzzaman C (2004). Chemical Composition of Crop Contents of Local Scavenging Chickens. Pakistan Journal of Nutrition, 3 (1): 26-28.

Roberts JA and Gunaratne SP (1992). The scavenging feed resource base for village chickens in a developing country. Proceedings of the XIX Worlds Poultry Congress, Amsterdam, 1:20-24.

SAS (2011). Statistical Analytical Systems / STAT user's guide).Version 9.3, Institute Inc., Cary, North Carolina.

Sonaiya EB, Branckaert RDS and Guèye EF (1999). Research and development options for family poultry. Introductory paper to the First INFPD/FAO electronic conference on family poultry, December 1998 to July 1999 (also available at http://www.fao.org/ag/aga/AGAP/LPA/fampo1/fampo/Intropap.htm).

SPSS (2002). Statistical Package for social Sciences. SPSS user's guide 20.0. SAS Institute Inc., Cary NC.

Tadelle D (1996). Studies on village poultry production systems in the Central Highlands of Ethiopia MSc. Thesis. Swedish University of Agricultural Sciences. Uppsala, Sweden.

Tadelle D and Ogle B (2000). Nutritional status of village poultry in the central high lands of Ethiopia as assessed by analyses of crop contents. Ethiopian Journal of Agricultural Sciences, 17: 47-57.

Tahir M, Shim MY, Ward NE, Smith C, Foster E, Guney AC and Pesti GM (2012). Phytate and other nutrient components of feed ingredients for poultry. Poultry Science 91:928-935.

Wisemam, J (1987). Feeding of Non-ruminant livestock. Butterworths. London, United Kingdom 913. 